\title{
Effect of Sand Fines and Water/Cement Ratio on Concrete Properties
}

\author{
Yalley P P* and Sam A \\ Department of Construction and Wood Technology, University of Education, Winneba-College of Technology Education, Ghana
}

Submission: January 24, 2018; Published: April 05, 2018

*Corresponding author: Yalley PP, Department of Construction and Wood Technology, University of Education, Winneba - College of Technology Education, Ghana, E-mail: ppyalley@gmail.com

\begin{abstract}
Sand fines (clay/silt) and water/cement ratio have been reported to be one of the causes of weakness in concrete strength. A study was conducted to determine the effect of fines content in sand and water/cement ratio on some properties of concrete. Fines content in sand of $2 \%$, $4 \%, 6 \%, 8 \%, 10 \%$ and $12 \%$ as well as water/cement ratio of $0.55,0.6$ and 0.7 were used. The concrete were prepared using the basic mix 1:2:4. Workability test on flesh concrete as well as compression and split tensile strengths were conducted in accordance with BS 1881 . The results show that, workability of concrete decreased as fines content increases. At the same level of fines content, workability increases when the W/C increased. The study again revealed that up to $4 \%$ fines content, compressive strength increased as the fines content increases. There was a decreased in the compressive strength with increased in all W/C. The same trend was found for the tensile splitting strength results. Predicting the effect of fines and W/C on work ability and strengths of concrete using regression analysis suggest that, over $80 \%$ of the variation in the workability and strengths were influenced by fines and W/C. It was concluded from the study that, fines content of $4 \%$ in sand and water/cement ratio of 0.55 is appropriate for concrete for structural use.
\end{abstract}

Keywords: Sand Fines; Water/cement Ratio; Workability; Strength; Concrete

Abbreviations: BS: British Standards; ASTM: American Standard for Testing and Materials

\section{Introduction}

Concrete is a very important material in the construction industry which is spearheading infrastructural development in Ghana leading to the expected prosperity and growth of the nation. The quality of concrete constituent materials controls its strength [1] which has also been found to be one of the causes of building collapse all over the world [2-4]. For this reason attention must be given to the factors which affect the strength of concrete [5-7].

Among these factors are sand fines which are materials that passes through the $75 \mu \mathrm{m}$ sieve. These fines are considered as an impurity in building sand in the BS882:1992 [8]. The presence of sand fines in concrete is likely to affect the workability, strength and long-term performance of concrete [9]. To this effect, the percentage limit of sand fines (clay/silt) is recommended by various building standards in other to check their effects on the strength of concrete. Some of which are the British Standards (BS), and the American Standard for Testing and Materials (ASTM) which recommends $4 \%$ and $10 \%$ of fines in building sand respectively. Nonetheless, Ghana is yet to specify the limit of fines (clay/silt) percentage in building sand for producing concrete. Moreover, it has been recommended by Danso and Boateng [10] to investigate the quality of building sand used in the Ghanaian construction industry which is yet to be realized.

Another contributing factor affecting concrete strength is the water content used which in some cases are increased to improve workability $[11,12]$. When the fines content in sand are excessive, there is the need to add more water to the concrete mix in other to improve the workability. That is fine particles such as clay and cement interact with water in a physiochemical state which leads to more absorption of water than that of fine and coarse aggregates. Research have shown that higher amount of sand fines in concrete results in poor workability. This eventually leads to the addition of water to the concrete mix before or even during the unloading process to improve workability [12].

Meanwhile, research have also shown that an increase in water/cement ratio result to a decrease in the compressive strength of concrete $[13,14]$. Additionally, the increase in sand fines content has also been found to decrease the compressive and tensile strengths of concrete $[15,16]$. Inadequate sand fine 


\section{Civil Engineering Research Journal}

content also has adverse effect of the strength of concrete due to poor adhesion. Researchers have therefore develop various models for predicting the effect of sand fines and W/C on the strength of concrete. However, there is a gap in literature for the combined effect of sand fines and water/cement ratio's effect on the properties of concrete. This paper seeks to address this gap in literature.

\section{Materials and Methods}

\section{Materials}

The materials used were crushed granite as coarse aggregate, natural pit sand, ordinary Portland cement and water. Physical properties of the aggregates were analysed. These properties included the specific gravity, water absorption, fineness modulus, surface texture, particle shape and colour. The specific gravity and water absorption were conducted in accordance with the ASTM C128:1997 for fine aggregate and ASTM C127:2007 for coarse aggregate.

\section{Testing methods and procedures}

Sample size: A total of 216 specimens were cast for strength testing. Out of this, 162 were made of $150 \mathrm{~mm}$ cubes for compressive strength testing at 7,28 and 91 days curing whereas 54 were made of $150 \times 300 \mathrm{~mm}$ cylinders for splitting tensile strength testing. The number of concrete batches prepared was Table 1: Concrete Mix Proportion for Casting Specimens.

\begin{tabular}{|c|c|c|c|c|}
\hline \multirow[t]{2}{*}{ Fines (\%) } & \multirow[t]{2}{*}{ Cement (kg) } & \multicolumn{2}{|c|}{ Sand (kg) } & \multirow{2}{*}{ Coarse Aggregate (kg) (12 mm max. size) } \\
\hline & & (Fines) & Normal Sand & \\
\hline 2 & 15.789 & 0.632 & 30.946 & 63.156 \\
\hline 4 & 15.789 & 1.263 & 30.315 & 63.156 \\
\hline 6 & 15.789 & 1.895 & 29.683 & 63.156 \\
\hline 8 & 15.789 & 2.526 & 29.052 & 63.156 \\
\hline 10 & 15.789 & 3.158 & 28.42 & 63.156 \\
\hline 12 & 15.789 & 3.789 & 27.789 & 63.156 \\
\hline \multicolumn{5}{|c|}{ Water Proportion in the Mix } \\
\hline \multicolumn{2}{|c|}{ Water/Cement Ratio } & 0.55 & 0.6 & 0.7 \\
\hline \multicolumn{2}{|c|}{ Amount (kg) } & 8.684 & 9.473 & 11.052 \\
\hline
\end{tabular}

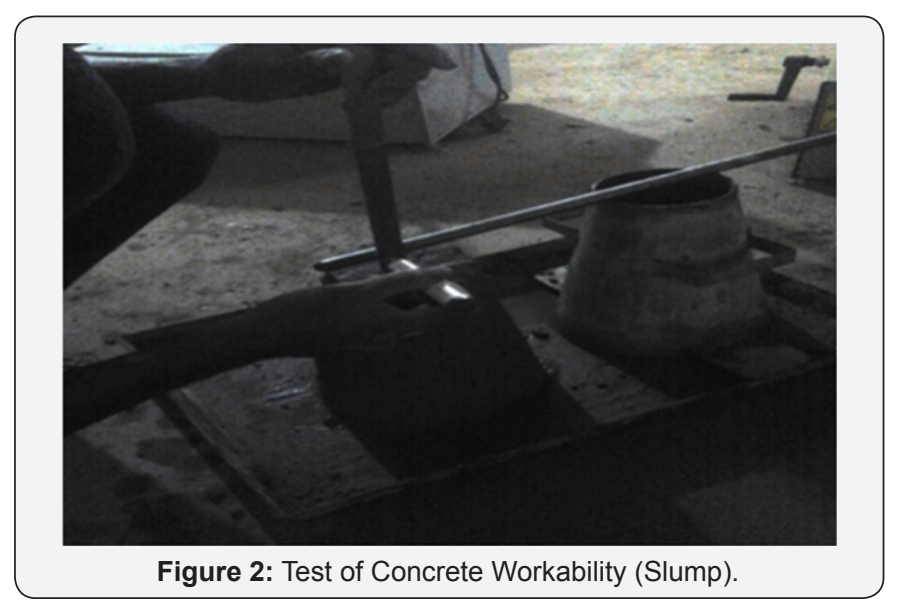

The amount of various materials needed for each mix proportion which could cast 9 cubes and 3 cylinders were batched for concrete mixing (Table 1). Different batches of concrete consisting sand with fines content of $2 \%, 4 \%, 6 \%$, $8 \%, 10 \%$ and $12 \%$ with three constant water/cement ratios of $0.55,0.60$ and 0.70 were prepared for the study. The amounts of coarse aggregate used were kept constant for all batches. The concrete were mixed using $1 \mathrm{~m}^{3}$ drum concrete mixer.

Workability test: Slump measurement was taken immediately after mixing each batch of concrete before casting them into specimen moulds (Figure 2). The moulds were coated with oil just before concrete casting. The concrete were cast in three layers into the moulds and each layer was tamped 25 times 


\section{Civil Engineering Research Journal}

with $16 \mathrm{~mm}$ diameter rod to removed entrapped airs present in the concrete. Excess concrete were cut away and the surface levelled with the trowel.

Curing of specimens: The specimens were initially cured in air for 24 hours. The moulds were then removed and were then immersed into water in a curing tank for 7, 28 and 91 days.

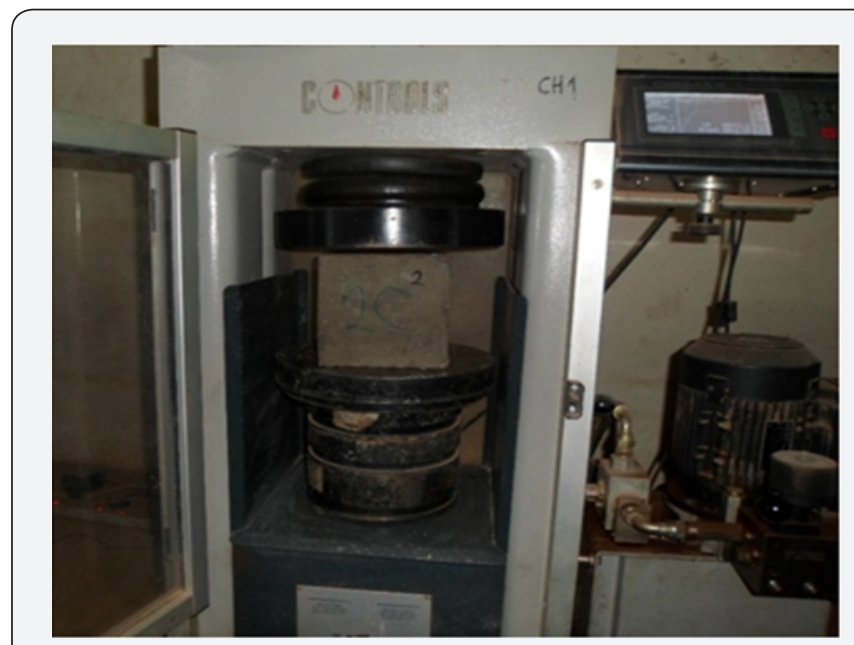

Figure 3: Test of Cube Specimen for Compression Strength.

Strength testing: Cube specimens for compressive strength test were conducted in accordance with the BS EN 123903 [17]. The cube specimens were inserted into a universal testing machine of which the surface of the cubes were aligned perpendicularly to the platens. An automatic loading rate within the range of $0.04 \mathrm{MPa} / \mathrm{s}$ to $0.06 \mathrm{MPa} / \mathrm{s}$ was applied to the specimen until failure occurred (Figure 3). The capacity of the testing machine was $2000 \mathrm{kN}$ maximum loading.

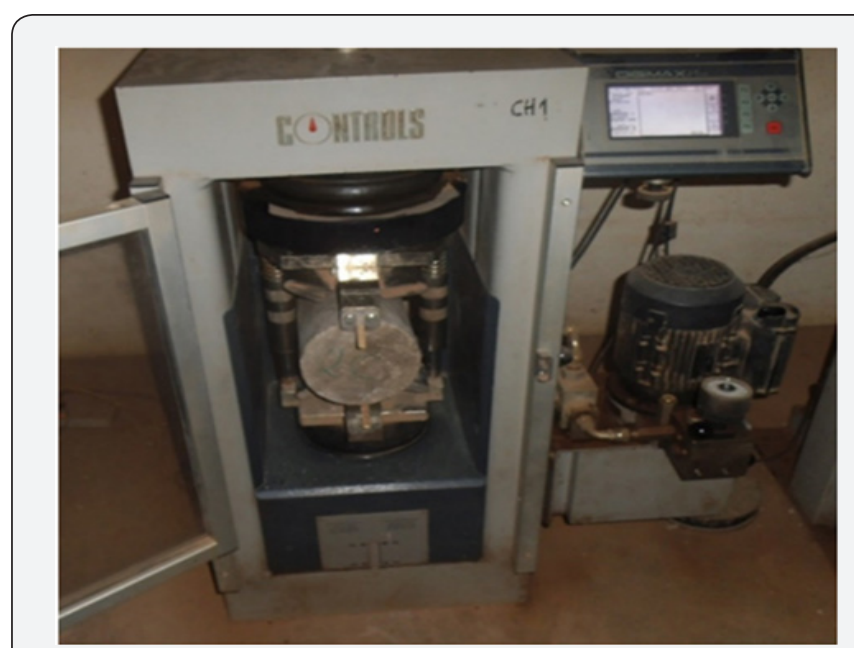

Figure 4: Test of Cylindrical Specimen for Splitting Tensile Strength.

The cylindrical specimens for splitting tensile strength test were conducted in accordance with the BS EN 12390-6 [18]. A diametrical compressive force was applied on the cylindrical specimens placed centrally with its axis horizontal between the platens of the universal testing machine. The specimen was supported in a jig with plywood used as parking strips conforming to EN 316. An automatic constant rate of loading within the range of $0.04 \mathrm{MPa} / \mathrm{s}$ to $0.06 \mathrm{MPa} / \mathrm{s}$ was applied without shock which increased continuously until splitting of specimen occurred (Figure 4).

\section{Results and Discussion}

\section{Physical properties of aggregates}

Table 2: Physical Properties of Study Aggregates.

\begin{tabular}{|c|c|c|}
\hline Property & Fine Aggregate & Coarse Aggregate \\
\hline Fines (\%) & 13.91 & - \\
\hline Specific gravity & 2.6 & 2.61 \\
\hline Water absorption (\%) & 1.4 & 0.5 \\
\hline Fineness modulus & 2.61 & 2.5 \\
\hline Surface texture & Rough & Rough \\
\hline Particle shape & Angular & Irregular \\
\hline Colour & Gray & Imperial gray \\
\hline
\end{tabular}

Table 2 gives the physical properties of the aggregates that were used for the study. The specific gravity of saturated surface-dry samples measured were 2.60 and 2.61 for fine and coarse aggregates respectively. This indicates the aggregates used for the study were within the accepted specified values for concrete production in accordance with BS EN 1097-6 [19]. The water absorption for the sand used was $1.4 \%$ which is below the specification limit of $2 \%$. This explains that, much of the water used for mixing the concrete will be absorbed by the aggregate to keep it at the saturated surface dry state and the rest for mixing the concrete and hydration of cement. The water absorption of coarse aggregate was $0.5 \%$ which was within the normal range from 0.1 to $0.6 \%$.The fineness modulus obtained suggest that, the aggregates used had an approximately average sizes of $600 \mu \mathrm{m}$ and $12.5 \mathrm{~mm}$ for fine and coarse aggregates respectively. Thus, the sand used was normal sand since it lies within Zone II of geological grading.

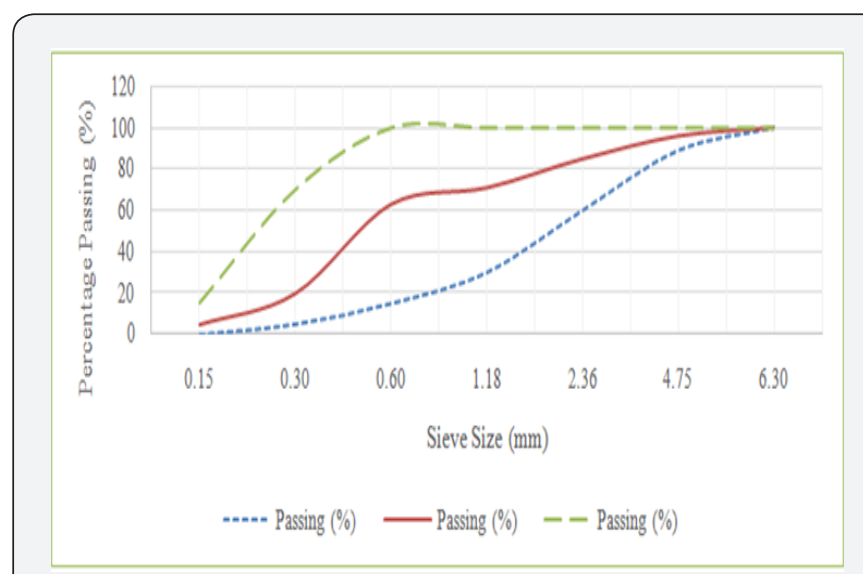

Figure 5: Test of Cylindrical Specimen for Splitting Tensile Strength.

The particle size distribution conducted in accordance with the BS882 were used to plot grading curve for the fine and coarse 


\section{Civil Engineering Research Journal}

aggregates shown in Figure $5 \& 6$ respectively. The grading curves and the physical properties given in Table 2 indicate the aggregates used for the study were within the accepted range for producing concrete.

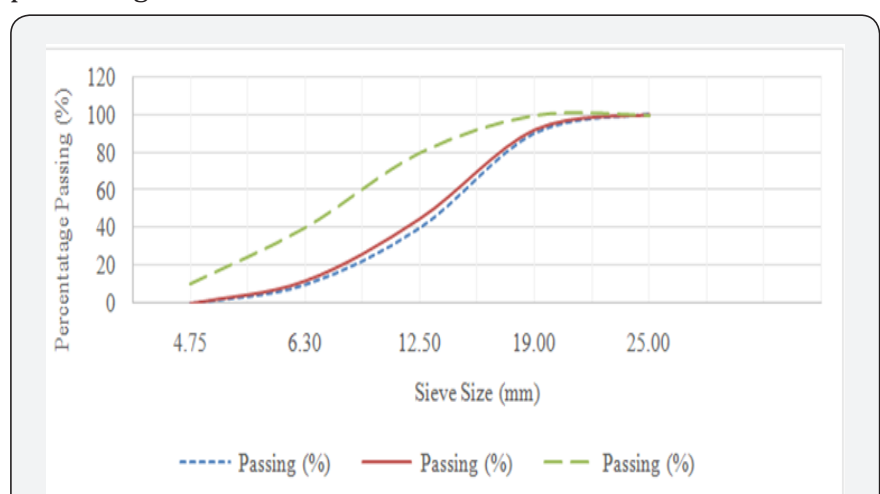

Figure 6: Grading Curve for Coarse Aggregates.

\section{Workability}

Table 3 presents the result of workability test given the slump values for the various mixing batches. It is noted that, slump values decreased as the fines percentage in sand increased whereas the slump increased as the water/cement ratio increased agreeing with earlier reports $[16,20,21]$. The decrease in slump value as a result of increase in fines percentage in sand can be attributed to the fact that finer particles have larger surface area which absorbs more water in concrete mix. Meanwhile, higher water/cement ratio is able to disperse the concrete constituents leading to a higher slump value. This result is again similar to the reports by Alawode and Idowu and Olusola et al. [13]. The degree of workability is explained in the Table 3 where concrete batches with 0.70 water/cement ratio had better slumps ranging from minimum of low to maximum of medium slump.

Table 3: Slump Values for Workability of Concrete.

\begin{tabular}{|c|c|c|c|c|c|}
\hline \multicolumn{3}{|c|}{ Water/Cement Ratio (w/c) } & \multicolumn{3}{|c|}{ Fines $(\%)$} \\
\hline \multirow{6}{*}{\multicolumn{3}{|c|}{0.55}} & \multicolumn{3}{|c|}{2} \\
\hline & & & \multicolumn{3}{|c|}{4} \\
\hline & & & \multicolumn{3}{|c|}{6} \\
\hline & & & \multicolumn{3}{|c|}{8} \\
\hline & & & \multicolumn{3}{|c|}{10} \\
\hline & & & \multicolumn{3}{|c|}{12} \\
\hline \multirow{6}{*}{\multicolumn{3}{|c|}{0.6}} & \multicolumn{3}{|c|}{2} \\
\hline & & & \multicolumn{3}{|c|}{4} \\
\hline & & & \multicolumn{3}{|c|}{6} \\
\hline & & & \multicolumn{3}{|c|}{8} \\
\hline & & & \multicolumn{3}{|c|}{10} \\
\hline & & & \multicolumn{3}{|c|}{12} \\
\hline \multirow{6}{*}{\multicolumn{3}{|c|}{0.7}} & \multicolumn{3}{|c|}{2} \\
\hline & & & \multicolumn{3}{|c|}{4} \\
\hline & & & \multicolumn{3}{|c|}{6} \\
\hline & & & \multicolumn{3}{|c|}{8} \\
\hline & & & \multicolumn{3}{|c|}{10} \\
\hline & & & \multicolumn{3}{|c|}{12} \\
\hline & \multicolumn{2}{|c|}{$\begin{array}{l}\text { Unstandardized } \\
\text { Coefficients }\end{array}$} & $\begin{array}{c}\text { Standardized } \\
\text { Coefficients }\end{array}$ & \multirow{2}{*}{$\mathbf{T}$} & \multirow{2}{*}{ Sig. } \\
\hline & B & $\begin{array}{l}\text { Std. } \\
\text { Error }\end{array}$ & Beta & & \\
\hline Constant & -141.905 & 18.367 & & -7.726 & 0 \\
\hline Fines $(F)$ & -235.714 & 52.989 & -0.364 & -4.448 & 0 \\
\hline $\begin{array}{c}\text { Water/ } \\
\text { Cement } \\
\text { Ratio } \\
(\mathrm{w} / \mathrm{c})\end{array}$ & 310.476 & 29.023 & 0.876 & 10.697 & 0 \\
\hline
\end{tabular}

Regression analysis was conducted to predict the relationship among the fines percentage in sand, water/ cement ratio and workability of concrete presented in Table

\begin{tabular}{|c|c|}
\hline Slump $(\mathrm{mm})$ & Degree of Workability \\
\hline 25 & Low \\
\hline 15 & Very low \\
\hline 13 & Very low \\
\hline 11 & Very low \\
\hline 9 & Very low \\
\hline 35 & Very low \\
\hline 30 & Low \\
\hline 26 & Low \\
\hline 24 & Low \\
\hline 19 & Very low \\
\hline 17 & Very low \\
\hline 95 & Very low \\
\hline 60 & Medium \\
\hline 56 & Medium \\
\hline 52 & Medium \\
\hline 49 & Medium \\
\hline 47 & Low \\
\hline
\end{tabular}

4. The coefficient of multiple determination, $\mathrm{R}^{2}$ given as 0.899 (Adjusted $\mathrm{R}^{2}=0.886$ ) indicates fines percentage in sand and water/cement ratio explains about $90 \%$ of the variations in concrete workability. Moreover, the ANOVA suggest the predicted equation is appropriate for determining the effects of fines percentage in sand and water/cement ratio on concrete workability $(\mathrm{F}=67.111, \mathrm{p}<0.001)$. From Table 4 , an increase in fines content in sand by one percent resulted to a decrease in concrete slump by approximately $236 \mathrm{~mm}$ when all other variables are kept constant. On the other hand, an increase in water/cement ratio by one unit (0.01) resulted to an increase in slump by approximately $310 \mathrm{~mm}$ with all other variables kept constant. The Beta values from the standardized coefficients suggest that, an increase of the fines percentage in sand by a 
standard deviation will result to a decrease in concrete slump on the average by $0.364 \mathrm{~mm}$. Meanwhile, an increase in the water/ cement ratio by one standard deviation will result to an increase in slump on the average by $0.876 \mathrm{~mm}$. Equation for predicting concrete workability is hence given as:

$\mathrm{Wc}=-141.905-235.714 \mathrm{~F}+310.476 \mathrm{w} / \mathrm{c}$ with $\mathrm{R}^{2}=89.9 \%$

(Eqn. 1)

Goodness of fit: $\mathrm{R}^{2}=89.9 \%$ (Adjusted $\mathrm{R}^{2}=88.6 \%$ ); $\mathrm{F}=67.111$, $\mathrm{p}<0.001$

\section{Compressive and tensile splitting strength}

The compressive strength of concrete cubes tested at 7, 28 and 91 days curing as well as splitting tensile strength tested at 28 days curing are presented in Table 5. It can be noted that, the strength of concrete (both compressive and tensile splitting) increased to $4 \%$ fines content in sand beyond which the strength decreased at constant water/cement ratio. The trend was found to be consistent with the report by Seeni et al. ; Cho [16]; Dammo et al. [22]; Iyappan and Manu [21]. Meanwhile, at constant fines content in sand, the compressive and tensile splitting strength of concrete decreased with an increase in water/cement ratio at all curing ages. This trend again supported previous investigation $[13,14,23]$. The reason may be that concrete with higher fines content in sand absorb more water thereby living inadequate amount of water for the hydration of cement leading to decreased strength. Moreover, higher percentage of fines in sand will require higher amount of water to make the concrete workable which intend result to lower strength of concrete. Thus, higher water/cement ratio disperse the concrete constituents resulting to less bridging of calcium-silicate-hydrate of cement hydration rendering weaker strength of concrete.

Table 5: Average Results of Concrete Compressive and Tensile Splitting Strength.

\begin{tabular}{|c|c|c|c|c|c|}
\hline \multirow[t]{2}{*}{ Water/Cement Ratio } & \multirow[t]{2}{*}{ Fines $(\%)$} & \multicolumn{3}{|c|}{ Compressive Strength $\left(\mathrm{N} / \mathrm{mm}^{2}\right)$} & \multirow{2}{*}{$\begin{array}{c}\text { Tensile SplittingStrength }\left(\mathrm{N} / \mathrm{mm}^{2}\right) \\
28 \text { Days }\end{array}$} \\
\hline & & 7 Days & 28 Days & 91 Days & \\
\hline \multirow{6}{*}{0.55} & 2 & 15.73 & 20.83 & 22.86 & 1.89 \\
\hline & 4 & 18 & 21.69 & 24.18 & 2.03 \\
\hline & 6 & 16.11 & 21.25 & 23.28 & 1.85 \\
\hline & 8 & 13.9 & 20.8 & 22.46 & 1.61 \\
\hline & 10 & 12.91 & 20.38 & 21.66 & 1.51 \\
\hline & 12 & 12.88 & 19.32 & 21 & 1.51 \\
\hline \multirow{6}{*}{0.6} & 2 & 14.16 & 18.96 & 20.82 & 1.71 \\
\hline & 4 & 15.62 & 19.93 & 21.45 & 1.83 \\
\hline & 6 & 12.98 & 19.57 & 20 & 1.75 \\
\hline & 8 & 12.12 & 15.78 & 18.99 & 1.69 \\
\hline & 10 & 12.09 & 15.77 & 17.47 & 1.62 \\
\hline & 12 & 11.61 & 13.23 & 15.77 & 1.5 \\
\hline \multirow{6}{*}{0.7} & 2 & 12.08 & 14.68 & 18.49 & 1.37 \\
\hline & 4 & 12.47 & 16.05 & 18.58 & 1.44 \\
\hline & 6 & 12.3 & 15.06 & 18.32 & 1.35 \\
\hline & 8 & 12.06 & 14.04 & 16.29 & 1.32 \\
\hline & 10 & 11.37 & 13.49 & 15.34 & 1.31 \\
\hline & 12 & 11.13 & 12.19 & 14.96 & 1.2 \\
\hline
\end{tabular}

Computing regression analysis as shown in Table 6 for predicting compressive strength of concrete at 28 days curing, the ANOVA indicates appropriate prediction using the model ( $\mathrm{F}$ $=41.998, \mathrm{p}<0.001$ ) however is valid for concrete with $4 \%$ fines and beyond. The coefficient of multiple determination, $\mathrm{R}^{2}=0.848$ (Adjusted $\mathrm{R}^{2}=0.828$ ) explains that fines percentage in sand and water/cement ratio explains about $85 \%$ of the variations in the compressive strength of concrete. The unstandardized coefficients indicates that an increase in fines content in sand by one percent will result to a decrease in compressive strength by $37.1 \mathrm{~N} / \mathrm{mm}^{2}$ when all other variables are kept constant. On the other hand, an increase in water/cement ratio by one unit (0.01) will cause a decrease in the 28-day compressive strength of concrete by $41.1 \mathrm{~N} / \mathrm{mm}^{2}$ keeping all other variables constant. Table 6 again indicates that an increase in fines percentage in sand by one standard deviation will cause a decrease in compressive strength of concrete cube on the average by $0.408 \mathrm{~N} / \mathrm{mm}^{2}$. The water/cement ratio when increased by one standard deviation will also decrease the compressive strength of concrete on the average by $0.826 \mathrm{~N} / \mathrm{mm}^{2}$. The predicting equation is therefore given as:

\section{$\mathrm{f}_{\text {cu, } 28}=45.4357-37.143 \mathrm{~F}-41.136 \mathrm{w} / \mathrm{c}$ with $\mathrm{R}^{2}=84.8 \%$ (Eqn. 2)}

Goodness of fit: $\mathrm{R}^{2}=84.8 \%$ (Adjusted $\mathrm{R}^{2}=82.8 \%$ ); $\mathrm{F}=$ 41.998, $\mathrm{p}<0.001$ 


\section{Civil Engineering Research Journal}

Table 6: Regression Coefficients of Compressive Strength.

\begin{tabular}{|c|c|c|c|c|c|}
\hline & \multicolumn{2}{|c|}{ Unstandardized Coefficients } & Standardized Coefficients & T & Sig. \\
\hline & B & Std. Error & Beta & 14.313 & 0 \\
\hline Constant & 45.357 & 3.169 & & -4.063 & 0.001 \\
\hline Fines (F) & -37.143 & 9.142 & -0.408 & -8.215 & 0 \\
\hline Water/Cement Ratio (w/c) & -41.136 & 5.007 & -0.826 & & 0 \\
\hline
\end{tabular}

Table 7 also presents the regression analysis for the tensile splitting strength of concrete. The coefficient of multiple determination, $\mathrm{R}^{2}$ indicates that, fines percentage in sand and water/cement ratio explains about $84 \%$ (Adjusted $\mathrm{R}^{2}=0.814$ ) of the variations in the tensile splitting strength of concrete. More so, the test statistic from the ANOVA suggest adequate prediction using the regression model developed ( $F=38.191$, $\mathrm{p}<0.001$ ) also valid for concrete with $4 \%$ fines and beyond. The unstandardized coefficients therefore indicate that, an increase of the fines content in sand by one percent will cause a decrease of $3.195 \mathrm{~N} / \mathrm{mm}^{2}$ in the tensile splitting strength of concrete when all other variables are kept constant. On the other hand, by keeping all other variables constant and increasing the water/ cement ratio by one unit (0.01) will result to a decrease in tensile splitting strength by $2.798 \mathrm{~N} / \mathrm{mm}^{2}$. Meanwhile, the standardized coefficients indicate that, an increase of fines percentage in sand by one standard deviation will cause an average decrease in tensile splitting strength of concrete by $0.485 \mathrm{~N} / \mathrm{mm}^{2}$. An increase in water/cement ratio by one standard deviation also decreased the tensile splitting strength of concrete on the average by $0.775 \mathrm{~N} / \mathrm{mm}^{2}$. This explains that water/cement ratio contributes the highest effect on concrete tensile splitting strength. The model predicting the tensile splitting strength is hence expressed as:

Table 7: Regression Coefficients of Tensile Splitting Strength.

\begin{tabular}{|c|c|c|c|c|c|}
\hline & \multicolumn{2}{|c|}{ Unstandardized Coefficients } & Standardized Coefficients & \multirow{2}{*}{ T } & \multirow{2}{*}{ Sig. } \\
\hline & B & Std. Error & Beta & 14.78 & 0 \\
\hline Constant & 3.532 & 0.239 & & -4.635 & 0 \\
\hline Fines (F) & -3.195 & 0.689 & -0.485 & -7.409 & 0 \\
\hline
\end{tabular}

$\mathrm{f}_{\mathrm{ct}, 28}=3.532-3.195 \mathrm{~F}-2.798 \mathrm{w} / \mathrm{c}$ with $\mathrm{R}^{2}=83.6 \%$

(Eqn. 3)

Goodness of fit: $\mathrm{R}^{2}=83.6 \%$ (Adjusted $\mathrm{R}^{2}=81.4 \%$ ); $\mathrm{F}=$ 38.191, $\mathrm{p}<0.001$

\section{Conclusion}

This study showed that, compressive strength of a cube specimen made from the basic 1:2:4 mix proportion using cement class of $32.5 \mathrm{R}$ is expected not to be less than $20 \mathrm{~N} / \mathrm{mm}^{2}$. On this note, it was concluded from the study results that, sand fines and water/cement ratio beyond $4 \%$ and 0.55 respectively significantly weakens the strength of concrete. It is recommended that sand used in Ghana for producing concrete should have fines limited to $4 \%$ maximum. Admixtures are also recommended to be used to improve workability instead of increasing water content with no recourse to cement addition during concrete production. Moreover, the chemical and biological composition of fines are recommended to be investigated to determine their influence on concrete properties.

\section{References}

1. Chudley R, Greeno R (1999) Construction Technology ( $3^{\text {rd }}$ ed.). England: Pearson Education Ltd.

2. Ede AN (2011) Measures to reduce the high incidence of structural failures in Nigeria. Journal of Sustainable Development in Africa 13(1): 153-161.

3. Ayedun CA, Durodola OA, Akinjare OA (2011) An empirical ascertainment of the causes of building failure and collapse in Nigeria. Mediterranean Journal of Social Sciences 3(1): 313-322.

4. Ngugi HN, Mutuku RN, Gariy ZA (2014) Effects of sand quality on the compressive strength of concrete: A case of Nairobi County and its Environs, Kenya. Open Journal of Civil Engineering 4(3): 255-273.

5. Olanitori LM (2006) Mitigating the effect of clay content of sand on concrete strength. $31^{\text {st }}$ Conference on our World in Concrete \& Structures. Singapore: CI-Premier PTE Ltd.

6. Savitha R (2012) Importance of quality assurance of materials for construction work. Build Materials Reseach and Testing Division, National Building Research Organization.

7. Desire TJ, Leopold M (2013) Impact of clay particles on concrete compressive strength. International Research Journal on Engineering 1(2): 049-056.

8. British Standards Institution (2002) Specification for aggregates from natural sources for concrete, BS882:1992. UK: British Standards Institution.

9. Gambhir ML (2002) Concrete manual: a laboratory manual for quality control of concrete. Delhi: Dhanpat Rai \& Co. Ltd.

10. Danso H, Boateng I (2013) Is the quality of cement a contributing factor for building collapse in Ghana? In S. L. Agyepong (Ed.), Procs 5th West Africa Built Environment Research (WEBER) Conference, (pp. 765-772). Accra, Ghana.

11. Reynolds CE, Steedman JC, Threlfall AJ (2008) Reynolds's reinforced concrete designer's handbook ( $11^{\text {th }}$ edn.). New York: Taylor \& Francis Group.

12. Cemex (2013) The effect of water addition to concretes: What's a little wate going to hurt? USA: Cemex USA - Technical Bulletin. 


\section{Civil Engineering Research Journal}

13. Olusola KO, Babafemi AJ, Umoh AA, Olawuyi BJ (2012) Effect of batching methods on the fresh and hardened properties of concrete. IJRRA, 3(3): 773 - 779.

14. Apebo AJ, Shiwua NS (2013) Effect of water-cement ratio on the compressive strength of gravel-crushed over burnt bricks concrete. Civil and Engineering Research 3(4): 74-81.

15. Olanitori LM (2012) Cost implication of mitigating the effect of clay/ silt content of sand on concrete compressive strength. Journal of Civil Engineering and Urbanism 2(4): 143-148.

16. Cho S (2013) Effect of silt fines on the durability properties of concrete. Journal of Applied Science and Engineering 16(4): 425-430.

17. British Standards Institution (2002) Testing hardened concrete - Part 3: Compressive strength of test specimens. BS EN12390-3:2002. UK British Standards Institution.

18. British Standards Institution (2000) Testing hardened concrete - Part 6: Tensile splitting strength of test specimens. BS EN12390-6:2000. UK: British Standards Institution.

19. British Standards Institution (2000) Testing for mechanical and physical properties of aggregate - Part 6: Determination of particle density and water absorption. London: British Standards Institution.
20. Ayodele FO, Ayeni IS (2015) Analysis of influence of silt/clay impurities present in fine aggregates on the compressive strength of concrete. International Journal of Engineering Research and Science \& Technology 4(4): 95-99.

21. Iyappan GR, Manu SS (2015) Experimental investigation on the effect of clay in sand for flexural behaviour r.c.c. beams. The international Journal of Science \& Technoledge 3(3): 118-124

22. Dammo MN, Deborah JM, Aghidi J, Isa A, Falmata AK (2014) Effect of Ngala clay on the compressive strrength of concrete. International Journal of Engineering Science Invention 3(7): 7-10.

23. Mallikarjunar RV, Seshagiri RM, Srilakshmi P, Sateesh KB (2013) Effect of w/c ratio on workability and mechanical properties of high strength self compacting concrete (M70 grade). International Journal of Engineering Research and Development 7(1): 06-13.

24. American Society for Testing and Materials (1997) Standard method of test for density, relative density (specific gravity), and absorption of fine aggregate. West Conshohocken: ASTM Intenational.

25. American Society for Testing and Materials (2007) Standard method of test for relative density (specific gravity), and absorption of coarse aggregate. West Conshohocken: ASTM International.

\section{Your next submission with Juniper Publishers} will reach you the below assets

- Quality Editorial service

- Swift Peer Review

- Reprints availability

- E-prints Service

- Manuscript Podcast for convenient understanding

- Global attainment for your research

- Manuscript accessibility in different formats

( Pdf, E-pub, Full Text, Audio)

- Unceasing customer service

Track the below URL for one-step submission https://juniperpublishers.com/online-submission.php 